\title{
Video Article \\ Measurement and Analysis of Extracellular Acid Production to Determine Glycolytic Rate
}

\author{
Shona A. Mookerjee ${ }^{1,2}$, Martin D. Brand ${ }^{1,2}$ \\ ${ }^{1}$ Touro University California College of Pharmacy \\ ${ }^{2}$ Buck Institute for Research on Aging
}

Correspondence to: Shona A. Mookerjee at shona.mookerjee@tu.edu, Martin D. Brand at mbrand@buckinstitute.org

URL: https://www.jove.com/video/53464

DOI: doi: $10.3791 / 53464$

Keywords: Biochemistry, Issue 106, oxygen consumption rate, extracellular acidification rate, extracellular flux, respiration, glycolysis

Date Published: 12/12/2015

Citation: Mookerjee, S.A., Brand, M.D. Measurement and Analysis of Extracellular Acid Production to Determine Glycolytic Rate. J. Vis. Exp. (106), e53464, doi:10.3791/53464 (2015).

\section{Abstract}

Extracellular measurement of oxygen consumption and acid production is a simple and powerful way to monitor rates of respiration and glycolysis ${ }^{1}$. Both mitochondrial (respiration) and non-mitochondrial (other redox) reactions consume oxygen, but these reactions can be easily distinguished by chemical inhibition of mitochondrial respiration. However, while mitochondrial oxygen consumption is an unambiguous and direct measurement of respiration rate ${ }^{2}$, the same is not true for extracellular acid production and its relationship to glycolytic rate ${ }^{3-6}$. Extracellular acid produced by cells is derived from both lactate, produced by anaerobic glycolysis, and $\mathrm{CO}_{2}$, produced in the citric acid cycle during respiration. For glycolysis, the conversion of glucose to lactate ${ }^{-}+\mathrm{H}^{+}$and the export of products into the assay medium is the source of glycolytic acidification. For respiration, the export of $\mathrm{CO}_{2}$, hydration to $\mathrm{H}_{2} \mathrm{CO}_{3}$ and dissociation to $\mathrm{HCO}_{3}{ }^{-}+\mathrm{H}^{+}$is the source of respiratory acidification. The proportions of glycolytic and respiratory acidification depend on the experimental conditions, including cell type and substrate(s) provided, and can range from nearly $100 \%$ glycolytic acidification to nearly $100 \%$ respiratory acidification ${ }^{6}$. Here, we demonstrate the data collection and calculation methods needed to determine respiratory and glycolytic contributions to total extracellular acidification by whole cells in culture using $\mathrm{C} 2 \mathrm{C} 12$ myoblast cells as a model.

\section{Video Link}

The video component of this article can be found at https://www.jove.com/video/53464/

\section{Introduction}

The overall goal of this method is to accurately measure the glycolytic rate of cells using extracellular flux analysis. Quantitative measurement of glycolytic rate using extracellular acidification is the desired endpoint of many experiments. However, the total rate of extracellular acidification is the sum of two components: respiratory acidification, in the form of $\mathrm{CO}_{2}$ (which hydrates to $\mathrm{H}_{2} \mathrm{CO}_{3}$ then dissociates to $\mathrm{HCO}_{3}{ }^{-}+\mathrm{H}^{+}$), and glycolytic acidification, in the form of lactate ${ }^{-}+\mathrm{H}^{+}$.

The contributions of $\mathrm{CO}_{2}$ to total extracellular acidification have until recently been considered negligible in the measurement platform used here, the XF24 analyzer ${ }^{7}$. However, it is clear in multiple other systems that $\mathrm{CO}_{2}$ can be a major contributor to extracellular acidification ${ }^{4-5}$. Multiple papers acknowledge this contribution, but do not attempt direct quantitation of $\mathrm{CO}_{2}$-derived acid ${ }^{3,8,9}$. We recently demonstrated quantitatively that $\mathrm{CO}_{2}$ production is a significant source of extracellular acidification in this system ${ }^{6}$. Moreover, though there are multiple metabolic pathways that generate $\mathrm{CO}_{2}$ from glucose catabolism, those carried out by matrix dehydrogenases in the citric acid cycle are the overwhelming contributors and all other sources generate amounts of $\mathrm{CO}_{2}$ that are within experimental error ${ }^{6}$.

Without correcting for $\mathrm{CO}_{2}$ production, extracellular acidification is therefore an ambiguous indicator of glycolytic rate and cannot be used quantitatively. Our previous publication highlights several instances where respiratory $\mathrm{CO}_{2}$ comprises the bulk of the total acidification signal, even in cells generally believed to primarily use glycolysis ${ }^{6}$. Additionally, the respiratory $\mathrm{CO}_{2}$ contribution to total acidification varies widely during the course of common metabolic profiling experiments, demonstrating that correct comparison of the glycolytic rate during different parts of an experiment requires correction for $\mathrm{CO}_{2}$.

To measure the glycolytic rate of cells using the rate of extracellular acidification, it is necessary to convert pH changes to changes in total $\mathrm{H}^{+}$ generated, and to subtract the extracellular acidification caused by $\mathrm{CO}_{2}$ released during operation of the citric acid cycle. Here, we describe a straightforward method for measuring extracellular proton production rate (from extracellular changes in $\mathrm{pH}$ and the calibrated buffering power of the assay medium) and $\mathrm{CO}_{2}$ production (from extracellular changes in $\mathrm{O}_{2}$ concentration), and demonstrate how to calculate glycolytic rate using these measurements.

This method strengthens the utility of extracellular acidification measurement by using it to properly calculate glycolytic rate as defined by lactate production. Without correction for respiratory $\mathrm{CO}_{2}$ (or direct measurement of lactate), it is impossible to determine if and to what extent the 
total acidification rate reflects glycolytic rate, confounding the interpretation of experiments that use total extracellular acidification as a direct measurement of lactate production.

\section{CALCULATIONS}

$\mathrm{CO}_{2}$ and lactate are, within experimental error, the only two contributors to extracellular acid production, based on experiments with myoblast cells ${ }^{6}$. Therefore, the rate of total extracellular acidification (PPR, proton production rate) can be defined as:

$\mathrm{PPR}_{\text {tot }}=\mathrm{PPR}_{\text {resp }}+\mathrm{PPR}_{\text {glyc }}$ Equation 1

where tot $=$ total; resp = respiratory; glyc $=$ glycolytic. Glycolytic PPR is thus:

$\mathrm{PPR}_{\text {glyc }}=\mathrm{PPR}_{\text {tot }}-\mathrm{PPR}_{\text {resp }} \quad$ Equation 2

Here,

$\mathrm{PPR}_{\text {tot }}=\mathrm{ECAR}_{\text {tot }} / \mathrm{BP} \quad$ Equation 3

where ECAR = extracellular acidification rate $(\mathrm{mpH} / \mathrm{min})$, and $\mathrm{BP}=$ buffering power $\left(\mathrm{mpH} / \mathrm{pmol} \mathrm{H}^{+}\right.$in $\left.7 \mu \mathrm{l}\right)$, while

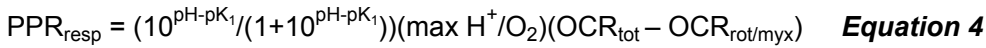

where $\mathrm{K}_{1}=$ combined equilibrium constant of $\mathrm{CO}_{2}$ hydration and dissociation to $\mathrm{HCO}_{3}{ }^{-}+\mathrm{H}^{+} ;$max $\mathrm{H}^{+} / \mathrm{O}_{2}=$ the $\mathrm{CO}_{2}$-derived acidification for a particular metabolic transformation such as complete oxidation of glucose ${ }^{6} ; \mathrm{OCR}=$ oxygen consumption rate $\left(\mathrm{pmol} \mathrm{O}_{2} / \mathrm{min}\right)$, and OCR $\mathrm{rot} / \mathrm{myx}=$ non-mitochondrial OCR.

Equation 4 isolates mitochondrial OCR by subtracting any non-mitochondrial OCR (defined as OCR that is resistant to the mitochondrial respiratory poisons rotenone and myxothiazol) and accounts for the maximum $\mathrm{H}^{+}$generated per $\mathrm{O}_{2}$ consumed for each substrate (max $\mathrm{H}^{+} /$ $\mathrm{O}_{2}$ ) $\left(\mathrm{see}^{6}\right)$, as well as the proportion of $\mathrm{CO}_{2}$ giving rise to $\mathrm{H}^{+}$at the experimental temperature and $\mathrm{pH}\left(10^{\mathrm{pH}-\mathrm{pK}_{1}} /\left(1+10^{\mathrm{pH}^{\mathrm{pk}}}\right)\right.$. For full oxidation of glucose, mitochondrial Oxygen Consumption Rate (OCR) is exactly equal to the rate of $\mathrm{CO}_{2}$ production. In the confined assay volume of extracellular flux measurement, $\mathrm{CO}_{2}$ produced by respiration remains trapped in the assay medium. Most of the trapped $\mathrm{CO}_{2}$ is hydrated to $\mathrm{H}_{2} \mathrm{CO}_{3}$, which then dissociates to $\mathrm{HCO}_{3}{ }^{-}+\mathrm{H}^{+}$. A small fraction remains dissolved but not hydrated, and another small fraction is hydrated but not dissociated, as dictated thermodynamically by the combined equilibrium constant of $\mathrm{CO}_{2}$ hydration and dissociation to $\mathrm{HCO}_{3}{ }^{-}+\mathrm{H}^{+}$at experimental temperature $\left(37^{\circ} \mathrm{C}\right)$ and $\mathrm{pH}(\sim 7.4)$.

Thus, the complete equation for calculating $\mathrm{PPR}_{\mathrm{g}}$ by subtracting $\mathrm{PPR}_{\text {resp }}$ from $\mathrm{PPR}_{\text {tot }}$ is:

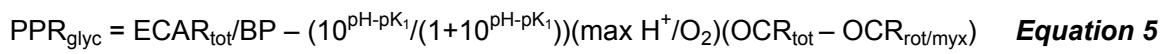

In this way, rates of respiration and glycolysis, as well as their associated ATP production rates, can be quantitatively determined from straightforward measurements (oxygen consumption, extracellular acidification, buffering capacity) and import or calculation of other required values $\left(\mathrm{H}^{+} / \mathrm{O}_{2}, \mathrm{P} / \mathrm{O} \text {, and the equilibrium constant } \mathrm{K}_{1}\right)^{6}$. The experiment described here expands on standard techniques for using the Extracellular Flux Analyzer such as Seahorse XF24 ${ }^{10,11}$; for other extracellular flux measurement formats (e.g., XF ${ }^{e} 96$, or XFp), all volumes below should be scaled appropriately.

The buffering power of the assay medium can be measured by construction of a standard curve either directly in the extracellular flux platform or separately using a calibrated $\mathrm{pH}$ probe. Here, three options for measuring buffering by the extracellular flux assay medium are given, including using all injection ports of the extracellular flux analyzer with cell-free sample wells, or using only the last injection port in cell-containing wells (section 1) or by using an external $\mathrm{pH}$ measurement (section 2). See the attached spreadsheet for the full calculations of example data.

To measure buffering power using the $\mathrm{pH}$-detecting capability of the extracellular flux instrument, it is safest to use cell-free wells to minimize signal variation. However, within the error, no statistical difference exists between cell-free and cell-containing wells when performing this measurement (data not shown). NOTE: The variation described in step 1.7 carries the advantage of accounting for any potential changes to buffering conferred by added compounds or by the presence of cells, with the disadvantage of noisier signal. However, as stated above, no significant differences were found in the calculated buffering power between the cell-free design shown in Table 1 and the post-experiment design in Table 2 under the experimental conditions described here.

Additionally, over small $\Delta \mathrm{pH}$ ranges ( $<0.4$ units; experimentally best restricted to 0.2 units), the linear slope obtained by plotting $\Delta \mathrm{mpH} / \mathrm{pmol}$ $\mathrm{H}^{+}$adequately approximates the logarithmic relationship between $\Delta \mathrm{pH}$ and $\left[\mathrm{H}^{+}\right]$. The slope of this standard curve therefore represents the buffering power of the assay medium under test in $\mathrm{pH} / \mathrm{nmol} \mathrm{H}^{+}$in $7 \mu \mathrm{l}$, or $\mathrm{mpH} / \mathrm{pmol} \mathrm{H}^{+}$in $7 \mu \mathrm{l}$. We recommend increasing medium buffering power or decreasing cell density for samples that exceed a $0.2 \mathrm{pH}$ unit change during the measurement time. The measurement time may also be decreased, but this may shorten the steady state acidification rate and introduce error into the rate calculation.

\section{Measuring Buffering Power in an Extracellular Flux Instrument: Two Variations}

NOTE: the calculations and methods described here were developed using an Extracellular Flux Analyzer. For other instruments, the measurement volume must be scaled appropriately.

1. Prepare $0.1 \mathrm{M}$ standard $\mathrm{HCl}$ in water using $\mathrm{HCl}$ concentrate (see Materials and Equipment) according to manufacturer instructions. 
Note: An example calculation for preparing $\mathrm{HCl}$ injections for use in all four injection ports is shown in Table 1:

\begin{tabular}{|c|c|c|c|c|c|c|c|c|c|}
\hline $\begin{array}{l}\text { Port ( } \mu \mathrm{L} \\
\text { injected) }\end{array}$ & Stock (mM) & Hl of stock & $\mu l$ of medium & $\begin{array}{c}\text { Resulting } \\
\text { change in } \mathrm{HCl} \\
\text { (mM) }\end{array}$ & $\begin{array}{c}\text { cumulative } \mathrm{HCl} \\
\text { (mM) }\end{array}$ & $\begin{array}{c}\mathrm{H}^{\prime} \text { in } 7 \mu \mathrm{L} \\
\text { (nmol) }\end{array}$ & $\mathrm{pH}(n=1)$ & $\begin{array}{c}\Delta \mathrm{pH} \text { (mean of } \\
n=10)\end{array}$ & SEM \\
\hline well & 100 & 0 & 0 & 0 & 0 & 0 & 7.37 & 0.000 & 0.000 \\
\hline$A(50)$ & 100 & 1.1 & 48.9 & 0.2 & 0.2 & 1.4 & 7.30 & 0.067 & 0.006 \\
\hline $\mathrm{B}(50)$ & 100 & 1.2 & 48.8 & 0.2 & 0.4 & 2.8 & 7.25 & 0.126 & 0.004 \\
\hline$C(50)$ & 100 & 13 & 487 & 02 & 0.6 & 4.2 & 7.18 & 0.195 & 0.005 \\
\hline $\mathrm{D}(50)$ & 100 & 1.4 & 48.6 & 0.2 & 0.8 & 5.6 & 7.13 & 0.252 & 0.005 \\
\hline
\end{tabular}

Table 1. Consecutive $\mathrm{HCl}$ injections into an extracellular flux assay well.

2. Prepare dilutions of the $\mathrm{HCl}$ standard in the medium to be assayed as in Table $\mathbf{1}$ for the number of technical replicates being carried out in one plate, plus one to allow for pipetting error; e.g., for four technical replicates of the port A injection, prepare a stock of $(1.1 \mu \mathrm{l} \times 5) 0.1 \mathrm{M}$ $\mathrm{HCl}$ in $(48.9 \mu \mathrm{l} \times 5)$ assay medium.

3. Distribute $50 \mu \mathrm{l}$ into each Port $\mathrm{A}$ of the measurement probe cartridge. Repeat this procedure for remaining ports $\mathrm{B}, \mathrm{C}$, and $\mathrm{D}$.

4. Run an extracellular flux assay ${ }^{10}$ with a standard calibration cycle, followed by two cycles of [ 2 min mix, 1 min wait, and 5 min measurement] for each of the four port additions (see Figure 2).

1. Program the experiment above in the instrument software according to software instructions. Load the prepared cartridge into the machine and perform calibration according to software instructions.

2. When prompted by the program, remove the calibrant-containing plate and insert the plate containing assay medium in each well into the instrument; continue the program.

5. Using the average of 8-10 data points obtained at steady state (typically the last 8-10 points) from before and after each port addition, calculate the (cumulative) difference in $\mathrm{pH}(\Delta \mathrm{pH})$ caused by each injection of standard acid.

6. Plot $\Delta \mathrm{pH}$ against $\mathrm{nmol} \mathrm{H} \mathrm{H}^{+}$contained in the $7 \mu \mathrm{l}$ volume trapped by the measurement probe. The linear slope is the buffering power (BP) in

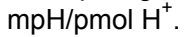

7. Alternatively to steps $1.2-1.3$, carry out the $\Delta \mathrm{pH}$ measurements following an assay in which Ports $\mathrm{A}, \mathrm{B}$, and $\mathrm{C}$ are used for conducting an experiment, followed by an $\mathrm{HCl}$ injection in Port $\mathrm{D}$. As in Table 2, four technical replicates are used to generate each point of a 5-point standard curve in the 20 experimental wells (excluding the four background temperature correction wells) of the extracellular flux assay plate.

Table 2: Single $\mathrm{HCl}$ injection into a cell-containing assay well, injecting $\mathrm{HCl}$ in a $50 \mu \mathrm{L}$ aliquot into Port $\mathrm{D}$, varying concentration between wells

\begin{tabular}{|c|c|c|c|c|c|c|c|c|}
\hline $\begin{array}{c}\text { Port }(\mu \mathrm{L} \\
\text { injected })\end{array}$ & Stock $(\mathrm{mM})$ & $\mu$ l of stock & $\mu$ l of medium & $\begin{array}{c}\text { Final in well } \\
(\mathrm{mM})\end{array}$ & $\begin{array}{c}\mathrm{H}^{*} \text { in } 7 \mu \mathrm{L} \\
(\mathrm{nmol})\end{array}$ & $\mathrm{pH}(\mathrm{n}=1)$ & $\begin{array}{c}\Delta \mathrm{pH}(\mathrm{mean} \text { of } \\
n=9)\end{array}$ & SEM \\
\hline $\mathrm{D}(50)$ & 100 & 0 & 50 & 0 & 0 & 7.35 & -0.010 & 0.003 \\
\hline $\mathrm{D}(50)$ & 100 & 0.7 & 49.3 & 0.1 & 0.7 & 7.33 & 0.025 & 0.003 \\
\hline $\mathrm{D}(50)$ & 100 & 1.4 & 48.6 & 0.2 & 1.4 & 7.28 & 0.069 & 0.013 \\
\hline $\mathrm{D}(50)$ & 100 & 3.5 & 46.5 & 0.5 & 3.5 & 7.16 & 0.186 & 0.011 \\
\hline $\mathrm{D}(50)$ & 100 & 7 & 43 & 1 & 7 & 7.03 & 0.332 & 0.034 \\
\hline
\end{tabular}

Table 2. Single $\mathrm{HCl}$ injection into an extracellular flux assay well.

\section{Measuring Buffering Power Using an External pH Meter}

NOTE: To measure the buffering power of a medium using an external $\mathrm{pH}$ probe, calibrate the probe at $37^{\circ} \mathrm{C}$ and maintain this temperature for all reagents during the experiment.

1. Prepare $0.1 \mathrm{M}$ standard $\mathrm{HCl}$ in water using $\mathrm{HCl}$ concentrate according to manufacturer instructions.

2. Warm $\mathrm{pH}$ probe, $\mathrm{pH}$ standards, the assay medium whose buffering power is to be measured, and $0.1 \mathrm{M} \mathrm{HCl}$ to $37^{\circ} \mathrm{C}$ in a water bath.

3. Calibrate $\mathrm{pH}$ probe at $37^{\circ} \mathrm{C}$ according to manufacturer instructions. Maintain all reagents at $37^{\circ} \mathrm{C}$ throughout the assay by using a heat plate or water bath.

4. Aliquot $10 \mathrm{ml}$ of the assay medium into a small beaker or conical tube. Monitor $\mathrm{pH}$ continuously using an immersed $\mathrm{pH}$ probe.

5. Add $0.1 \mathrm{M} \mathrm{HCl}$ to the assay medium in $10-20 \mu \mathrm{l}$ aliquots.

1. Ensure mixing by using a stir bar or by manually swirling the container after each acid addition.

2. Allow a few seconds for the $\mathrm{pH}$ measurement to stabilize, then record the $\mathrm{pH}$ after each addition.

3. As demonstrated in Table 3, make a sufficient number of additions to ensure accurate slope calculation and to cover the $\mathrm{pH}$ range expected during the experiment. 
Table 3: Measuring buffering power using a pH meter. Adding $\mathrm{HCl}$ in $0.2 \mathrm{mM}$ increments to $10 \mathrm{~mL}$ assay medium. Plotting $\Delta \mathrm{pH}$ vs $\mathrm{nmol} \mathrm{H}^{+}$added per $7 \mu \mathrm{L}$ volume yields buffering power (BP) as the slope of the graph.

\begin{tabular}{|r|r|r|r|r|r|r|r|r|}
\hline $\begin{array}{c}\text { Assay } \\
\text { Medium }(\mu \mathrm{L})\end{array}$ & $\begin{array}{c}\mathrm{HCl} \text { stock } \\
(\mathrm{mM})\end{array}$ & $\begin{array}{c}\mathrm{HCl} \text { added } \\
(\mu \mathrm{L})\end{array}$ & $\begin{array}{c}\text { resulting } \\
\text { change in } \mathrm{HCl} \\
(\mathrm{mM})\end{array}$ & $\begin{array}{c}\text { cumulative } \\
\mathrm{HCl}(\mathrm{mM})\end{array}$ & $\begin{array}{c}\mathrm{H}^{+} \text {in } 7 \mu \mathrm{L} \\
(\mathrm{nmol})\end{array}$ & $\mathrm{pH}$ (example) & $\begin{array}{c}\Delta \mathrm{pH}(\mathrm{mean} \\
\text { of } \mathrm{n}=4)\end{array}$ & SEM \\
\hline 10000.00 & 0.00 & 0.00 & 0.00 & 0.00 & 0.00 & 7.29 & 0.00 & 0.01 \\
\hline 10000.00 & 100.00 & 20.00 & 0.20 & 0.20 & 1.40 & 7.24 & 0.06 & 0.02 \\
\hline 10020.00 & 100.00 & 20.04 & 0.20 & 0.40 & 2.80 & 7.17 & 0.12 & 0.02 \\
\hline 10040.04 & 100.00 & 20.08 & 0.20 & 0.60 & 4.20 & 7.11 & 0.18 & 0.01 \\
\hline 10060.12 & 100.00 & 20.12 & 0.20 & 0.80 & 5.60 & 7.04 & 0.26 & 0.03 \\
\hline 10080.24 & 100.00 & 20.16 & 0.20 & 1.00 & 7.00 & 6.94 & 0.34 & 0.03 \\
\hline
\end{tabular}

Table 3. Measuring buffering power using a pH meter. Data represent a typical experiment with six $20 \mu \mathrm{l}$ additions of $0.1 \mathrm{M} \mathrm{HCl}$.

6. Plot $\Delta \mathrm{pH}$ against $\mathrm{nmol} \mathrm{H}^{+}$added per $7 \mu$, giving a linear slope that represents the buffering power (Figure 1).

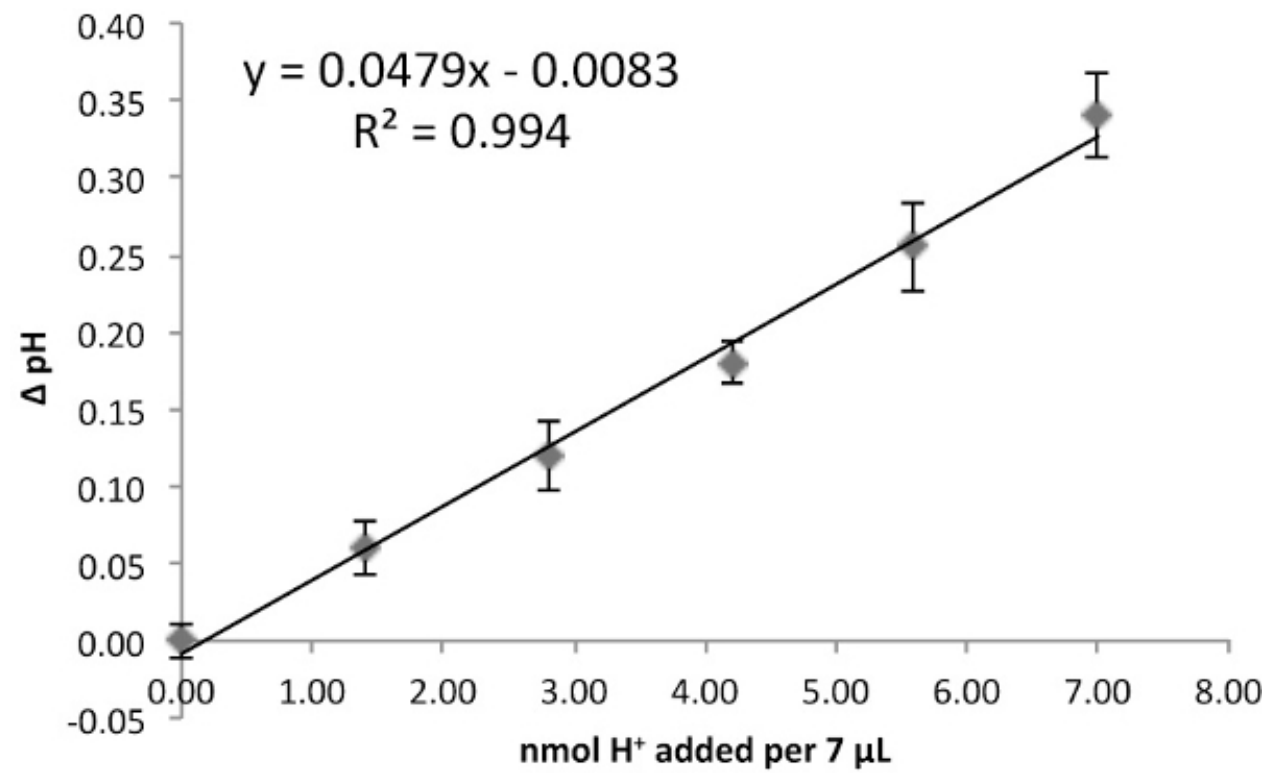

Figure 1. Determining buffering power. $\mathrm{HCl}$ standard curve measured as in Table 1, Table 2 or (here) as in Table 3 . The slope of the linear curve fit gives the buffering power $\left(\mathrm{pH} / \mathrm{nmol} \mathrm{H}^{+}\right.$in $\left.7 \mu \mathrm{l}\right)$. Each point represents mean $\pm \mathrm{SEM}$ of $\mathrm{n}=9$ technical replicates.

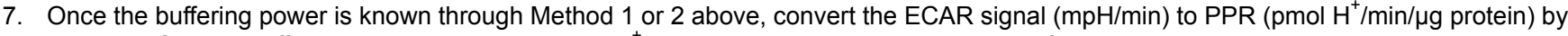
dividing ECAR by buffering power (BP) $\left(\mathrm{mpH} / \mathrm{pmol} \mathrm{H}^{+}\right)$and scaling to the protein content of each well:

$\mathrm{PPR}_{\text {tot }}(\mathrm{pmol} \mathrm{H} / \mathrm{min} / \mu \mathrm{g}$ protein $)=\operatorname{ECAR}(\mathrm{mpH} / \mathrm{min}) / \mathrm{BP}\left(\mathrm{mpH} / \mathrm{pmol} \mathrm{H}{ }^{+}\right.$in $\left.7 \mu \mathrm{l}\right) /$ protein per well $(\mu \mathrm{g}) \quad$ Equation 6

8. Alternatively, use the same experiments in Methods 1 or 2 to calculate the Buffering Capacity (BC) value used by the instrument software to automatically calculate PPR during data collection.

NOTE: The instrument user manual ${ }^{12}$ (page 107) provides detailed information about calculating and using buffering capacity, where BC is described as

$\mathrm{BC}(\mathrm{mol} / \mathrm{L})=$ moles $\mathrm{H}^{+} /(\Delta \mathrm{pH} \times$ buffer volume $(\mathrm{L})) \quad$ Equation 7

NOTE: The buffering capacity as defined in Equation 7 can be calculated in the instrument or external pH probe assays described above.

Conversion between buffering power and buffering capacity is easily done (see attached spreadsheet):

$\mathrm{BC}=1 \times 10^{-9} / \mathrm{BP}\left(\left(\mathrm{mpH} / \mathrm{pmol} \mathrm{H}{ }^{+}\right.\right.$in $\left.\left.7 \mu \mathrm{l}\right) / 7 \mu \mathrm{l}\right) \quad$ Equation 8

NOTE: If known prior to performing the assay, the buffering capacity can be entered directly into the instrument software during experimental setup.

9. Apply this procedure and the calculations used above to most conventional buffer systems, as described in previous publication ${ }^{6}$

NOTE: Table 4 lists the buffering power and buffering capacity of several conventional media. 


\begin{tabular}{|c|c|c|c|c|}
\hline $\begin{array}{l}\text { Assay } \\
\text { medium }\end{array}$ & $\begin{array}{c}\text { Volume of } \\
\text { medium } \\
(\mathrm{L})\end{array}$ & $\begin{array}{c}\mathrm{BP} \\
(\mathrm{mpH} / \mathrm{pmol} \\
\left.\mathrm{H}^{+} / 7 \mu \mathrm{L}\right)\end{array}$ & $\begin{array}{c}\mathrm{BC}(\mathrm{mol} \\
\left.\mathrm{H}^{+} / \mathrm{L}^{*} \Delta \mathrm{pH}\right)\end{array}$ & Composition \\
\hline $\begin{array}{c}\text { KRPH } \\
0.1 \% \text { BSA }\end{array}$ & 7.00E-06 & 0.045 & 0.0032 & $\begin{array}{l}2 \mathrm{mM} \mathrm{HEPES}, 136 \mathrm{mM} \mathrm{NaCl}, 2 \mathrm{mM} \mathrm{NaH}_{2} \mathrm{PO}_{4}, 3.7 \\
\mathrm{mM} \mathrm{KCl}, 1 \mathrm{mM} \mathrm{MgCl} \\
2,1.5 \mathrm{mM} \mathrm{CaCl}_{2}, 0.1 \% \text { w/v fatty } \\
\text { acid-free bovine serum albumin, } \mathrm{pH} 7.4 \text { at } 37^{\circ} \mathrm{C}\end{array}$ \\
\hline $\begin{array}{c}\text { KRPH } 1 \% \\
\text { BSA }\end{array}$ & 7.00E-06 & 0.035 & 0.0041 & $\begin{array}{l}2 \mathrm{mM} \text { HEPES, } 136 \mathrm{mM} \mathrm{NaCl}, 2 \mathrm{mM} \mathrm{NaH}_{2} \mathrm{PO}_{4}, 3.7 \\
\mathrm{mM} \mathrm{KCl}, 1 \mathrm{mM} \mathrm{MgCl} \\
\text { acid-free bovine serum albumin, } \mathrm{pH} 7.4 \text { at } 37^{\circ} \mathrm{C}\end{array}$ \\
\hline $\begin{array}{c}\text { minimal } \\
\text { TES buffer }\end{array}$ & 7.00E-06 & 0.010 & 0.0143 & $\begin{array}{l}3.5 \mathrm{mM} \mathrm{KCl}_{1} 120 \mathrm{mM} \mathrm{NaCl} 1.3 \mathrm{mM} \mathrm{CaCl}, 0.4 \mathrm{mM} \\
\mathrm{KH}_{2} \mathrm{PO}_{4}, 1.2 \mathrm{mM} \mathrm{Na}_{2} \mathrm{SO}_{4}, 2 \mathrm{mM} \mathrm{MgCl}, 15 \mathrm{mM} \\
\text { glucose, } 20 \mathrm{mM} \mathrm{TES} \text {, and } 0.3 \% \text { w/v fatty-acid-free } \\
\text { bovine serum albumin, pH } 7.4 \text { at } 37^{\circ} \mathrm{C}\end{array}$ \\
\hline XF DMEM & 7.00E-06 & 0.100 & 0.0014 & $\begin{array}{l}\text { XF DMEM containing } 5 \mathrm{mM} \text { glucose, } 2 \mathrm{mM} \\
\text { glutamine, } 0.4 \mathrm{mM} \text { sodium pyruvate, } \mathrm{pH} 7.4 \text { at } 37 \\
{ }^{\circ} \mathrm{C}\end{array}$ \\
\hline XF RPMI & $7.00 \mathrm{E}-06$ & 0.041 & 0.0035 & $\begin{array}{l}\text { XF RPMI (bicarbonate-free) containing } 11 \mathrm{mM} \\
\text { glucose, } 2 \mathrm{mM} \text { glutamine, } 1 \mathrm{mM} \mathrm{NaH}_{2} \mathrm{PO}_{4}, \mathrm{pH} 7.4 \\
\text { at } 37^{\circ} \mathrm{C}\end{array}$ \\
\hline
\end{tabular}

Table 4. Buffering power and buffering capacity of selected media.

\section{Performing an Extracellular Flux Assay Using C2C12 Myoblast Cells}

NOTE: In step 3.4.3, there were no observed differences in $\mathrm{CO}_{2}$-derived acid production dependent on the presence of carbonic anhydrase in $\mathrm{C} 2 \mathrm{C} 12$ culture, suggesting that its presence is not required for full conversion of $\mathrm{CO}_{2}$ to $\mathrm{HCO}_{3}^{-}+\mathrm{H}^{+}$. However, empirically testing this in different experimental systems is recommended before omitting carbonic anhydrase.

1. Culture mouse $\mathrm{C} 2 \mathrm{C} 12$ myoblasts ${ }^{13}$ at $37{ }^{\circ} \mathrm{C}$ under $95 \%$ air $/ 5 \% \mathrm{CO}_{2}$ in Dulbecco's modified Eagle medium (DMEM) with $11.1 \mathrm{mM}$ glucose, 2 $\mathrm{mM}$ glutamine, $10 \% \mathrm{v} / \mathrm{v}$ fetal bovine serum (FBS), $100 \mathrm{U} / \mathrm{ml}$ penicillin and $100 \mu \mathrm{g} / \mathrm{ml}$ streptomycin.

2. $24 \mathrm{hr}$ prior to assay, plate/seed cells in $100 \mu \mathrm{l}$ of the same culture medium at 20,000 cells/well in a 24-well polystyrene extracellular flux assay plate (see Materials and Methods) with no additional coating.

3. Dilute oligomycin, $\mathrm{FCCP}$, and rotenone plus myxothiazol, and $\mathrm{HCl}$ (optional) to 10x final concentration in Krebs Ringer Phosphate HEPES (KRPH) assay medium (2 mM HEPES, $136 \mathrm{mM} \mathrm{NaCl}, 2 \mathrm{mM} \mathrm{NaH} \mathrm{PO}_{4}, 3.7 \mathrm{mM} \mathrm{KCl}, 1 \mathrm{mM} \mathrm{MgCl}, 1.5 \mathrm{mM} \mathrm{CaCl}, 0.1 \%$ w/v fatty-acid-free bovine serum albumin, $\mathrm{pH} 7.4$ at $\left.37^{\circ} \mathrm{C}\right)$.

4. Cell preparation

1. $30 \mathrm{~min}$ prior to the assay, wash adherent cells three times by aspirating to gently remove the medium from the well and then slowly adding $500 \mu \mathrm{KRPH}$.

2. Incubate cells after the third wash step at $37^{\circ} \mathrm{C}$ under air (not under $5 \% \mathrm{CO}_{2}$, which will alter the pH of this bicarbonate-free medium).

3. At assay start, replace $\mathrm{KRPH}$ in wells with $500 \mu \mathrm{l}$ fresh $\mathrm{KRPH}$ containing $500 \mathrm{U} / \mathrm{ml}$ carbonic anhydrase and either glucose (10 mM) or medium only, with no additional substrate.

5. Loading the sensor cartridge

1. Pipet $50 \mu \mathrm{l}$ aliquots of each $10 \mathrm{x}$ compound prepared in Step 3.3 into cartridge ports of an extracellular flux sensor cartridge as follows (final concentrations in assay well given): Port A: $2 \mu \mathrm{g} / \mathrm{ml}$ oligomycin, Port B: $0.5 \mu \mathrm{M} \mathrm{FCCP}$, Port C: $1 \mu \mathrm{M}$ rotenone, $1 \mu \mathrm{M}$ myxothiazol, Port D: $\mathrm{HCl}$ (if performing an in-assay acid calibration as described above and in Table 2).

NOTE: for the purpose of complete respiratory chain inhibition described here, $1 \mu \mathrm{M}$ myxothiazol may be used interchangeably with 1 $\mu \mathrm{M}$ antimycin $\mathrm{A}$.

6. Extracellular flux assay:

1. Perform a standard extracellular flux assay for determining respiratory control as described in ${ }^{10}$. 
NOTE: For each segment of the experiment, determine the mix, wait, and measurement times desired, as well as the number of cycles per segment.

NOTE: The data in Table 5 were collected over two assay cycles of $2 \mathrm{~min}$ mix, 1 min wait, and 5 min measure for each segment, with three assay cycles occurring after the Port $\mathrm{D}$ addition of different amounts of $\mathrm{HCl}$ (for calibration of buffering power as in Table 2).

\begin{tabular}{|c|c|c|}
\hline \multicolumn{3}{|c|}{ Table 5: Seahorse assay configuration } \\
\hline & Command & Time (min) \\
\hline & Calibrate & 0.00 \\
\hline & Equilibrate & \\
\hline \multirow{3}{*}{2 Cycles } & Mix & 2.00 \\
\hline & Wait & 1.00 \\
\hline & Measure & 5.00 \\
\hline & Inject & Port A (oligomycin) \\
\hline \multirow{3}{*}{2 Cycles } & Mix & 2.00 \\
\hline & Wait & 1.00 \\
\hline & Measure & 5.00 \\
\hline & Inject & Port B (FCCP) \\
\hline \multirow{3}{*}{2 Cycles } & Mix & 2.00 \\
\hline & Wait & 1.00 \\
\hline & Measure & 5.00 \\
\hline & Inject & Port C (rot/myx) \\
\hline \multirow{4}{*}{2 Cycles } & Mix & 2.00 \\
\hline & Wait & 1.00 \\
\hline & Measure & 5.00 \\
\hline & Inject & Port $\mathrm{D}(\mathrm{HCl})$ \\
\hline \multirow{3}{*}{3 Cycles } & Mix & 1.00 \\
\hline & Wait & 0.50 \\
\hline & Measure & 5.00 \\
\hline
\end{tabular}

Table 5. Extracellular flux assay configuration.

\section{Measuring End-point Lactate Concentration}

NOTE: To validate the indirect assay described here in some different system, end point lactate concentration at the end of an extracellular flux experiment can be determined directly in a conventional 96 -well plate by measuring the initial velocity (over 2 min) of reduction of NAD $\rightarrow$ $\mathrm{NADH}$ catalyzed by lactate dehydrogenase, described in detail in our prior publication ${ }^{6}$. For the data presented in Representative Results, the end point lactate concentration in glucose-containing assay wells was $\sim 40 \mu \mathrm{M}$.

1. Prepare $2 x$ hydrazine medium: $1 \mathrm{M}$ Tris, $20 \mathrm{mM}$ EDTA, $400 \mathrm{mM}$ hydrazine, $\mathrm{pH} 9.8$ at $\left.22^{\circ} \mathrm{C}\right)$. Immediately before assay start, add $\mathrm{NAD}{ }^{+}$to 4 $\mathrm{mM}$ and lactate dehydrogenase (LDH) to $40 \mathrm{U} / \mathrm{ml}$. Final assay medium composition (1x): $500 \mathrm{mM}$ Tris, $10 \mathrm{mM}$ EDTA, $200 \mathrm{mM}$ hydrazine, 2 $\mathrm{mM} \mathrm{NAD}{ }^{+}, 20 \mathrm{U} / \mathrm{ml} \mathrm{LDH}$.

2. Immediately following the extracellular flux assay, remove $100 \mu \mathrm{l}$ of assay medium from each well of the extracellular flux assay plate and transfer to a well of an opaque (black) 96-well plate.

3. To each sample well, add $100 \mu \mathrm{l} 2 \mathrm{x}$ hydrazine medium.

4. Immediately load the plate into a microplate reader and begin monitoring NADH fluorescence at $340 \mathrm{~nm}$ excitation/460 nm emission.

5. Record the initial velocity for approximately $2 \mathrm{~min}$.

6. Run a similar experiment to construct a standard curve by plotting initial velocity against lactate concentration for added lactate concentrations from 0 to $50 \mu \mathrm{M}$.

7. Calculate lactate concentration in each experimental well using the standard curve. 


\section{Measuring Protein Content}

1. Remove remaining assay medium from each well of the assay plate.

2. Wash wells three times with $250 \mu \mathrm{BSA}$-free $\mathrm{KRPH}$, being careful to minimize the dislodging of cells from the bottom well surface.

3. Add $25 \mu \mathrm{l}$ RIPA lysis medium ( $150 \mathrm{mM} \mathrm{NaCl}, 50 \mathrm{mM}$ Tris, $1 \mathrm{mM}$ EGTA, $1 \mathrm{mM}$ EDTA, $1 \%$ v/v Triton X-100, 0.5\% w/v sodium deoxycholate, $0.1 \% \mathrm{v} / \mathrm{v}$ SDS, $\mathrm{pH} 7.4$ at $22^{\circ} \mathrm{C}$ ) to each well of the assay plate.

4. Incubate plate on ice for $30 \mathrm{~min}$.

5. Agitate plate on a plate shaker at $1,200 \mathrm{rpm}$ for $5 \mathrm{~min}$.

6. Measure protein concentration by standard methods, e.g., by BCA assay, ensuring that the lysis buffer composition is compatible with the measurement method. The protein content in the experiment in Figure 2 was $\sim 4 \mu \mathrm{g} / \mathrm{well}$.

\section{Representative Results}

Figure 2 shows the raw data for a typical experiment. The last 10 measurement points from the point-to-point recording of both OCR and $\mathrm{pH}$ (shaded vertical bars) were used for the calculations. Initial concerns that the average value (middle point measurement) of each assay cycle would not provide sufficient resolution of rate for an accurate calculation, particularly as there appeared to be a slight lag between port addition and steady state acidification rate, were not borne out, as this does not appear to contribute significantly to calculation error (not shown). Alternatively, if the correct buffering capacity is entered during experimental setup, PPR can be read directly from the instrument data collection readout by displaying the PPR output in the instrument software or in the PC-compatible format available as one of the data output settings.

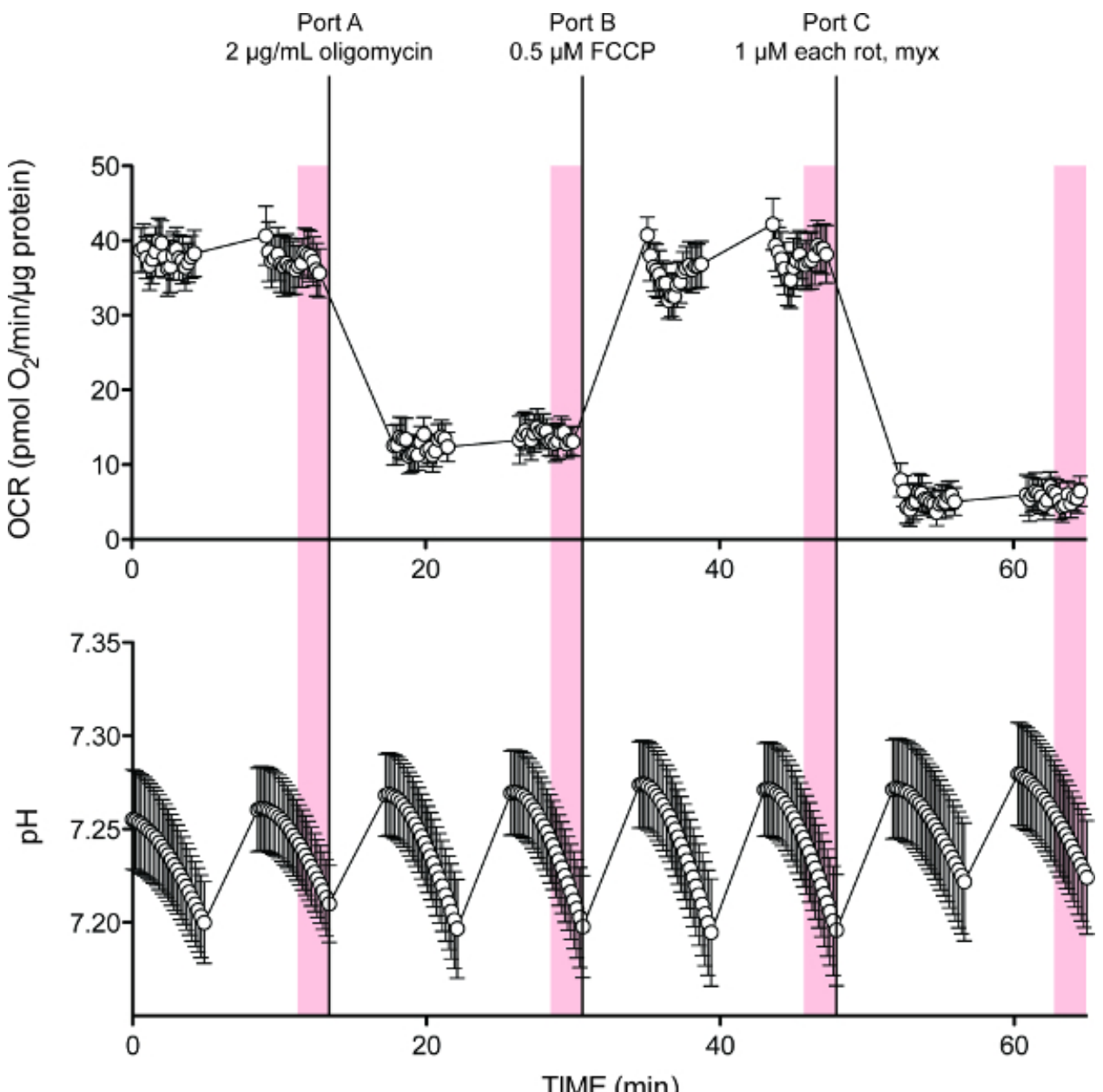

Figure 2. Representative extracellular flux traces of $\mathrm{O}_{2}$ and $\mathrm{H}^{+}$. OCR and $\mathrm{pH}$ traces for the example experiment in Table 5 , containing $10 \mathrm{mM}$ glucose at assay start. Port $\mathrm{D}$ had different $\mathrm{HCl}$ concentrations for calibration of buffering power (not shown in these averaged traces). Data from previous publication ${ }^{6}$. Each point represents mean \pm SEM of $n=8$ biological replicates. Please click here to view a larger version of this figure.

\section{Data analysis of representative results}

Using the spreadsheet shown in Table 6 and provided as an attachment, data values from individual wells may be entered in the columns shown with yellow headers. All six columns to the right are calculated from these entries. The example in Table 6 shows the calculations of PPR ${ }_{\text {resp }}$ and $\mathrm{PPR}_{\mathrm{glyc}}$ using ECAR and OCR data from individual wells for the native conditions with or without added glucose, prior to Port A addition of oligomycin. Technical replicates on each biological preparation are normally averaged to give single values of the outputs in the last four 
columns, then data from different biological preparations are averaged with appropriate propagation of error statistics in BP and these four values.

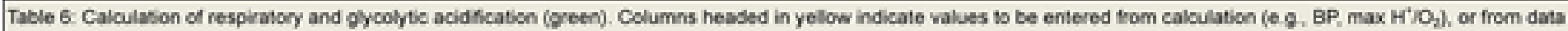

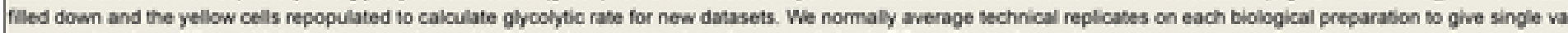
average data from diflecent biological preparations with appropriate propagation of error statistics in BP and these four values.

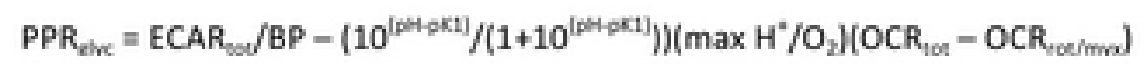

\begin{tabular}{|c|c|c|c|c|c|c|c|c|c|c|c|c|c|}
\hline idencfier & medun & PH & 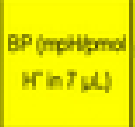 & 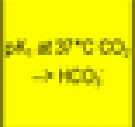 & cell Mose & suceryat & matrop & probein in wet & $\begin{array}{l}\text { OCR. (pond } \\
\text { Q/min) }\end{array}$ & (tmolo/mint) & $\begin{array}{l}\text { ECAR } \\
\text { (mptymint) }\end{array}$ & 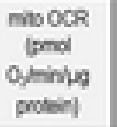 & 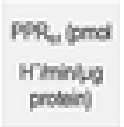 \\
\hline examcib expl 1 & KFHONYREA & 7.40 & 0055 & 6009 & Cx:12 & guable $10 \mathrm{~m}$. & 100 & 4.10 & 13420 & 2040 & 2025 & 400 & 109 \\
\hline exancile expt 2 & KFPHO.FSGBSA & 7.40 & 0.045 & 6.083 & $\mathrm{CrCl}_{2}$ & sone & 100 & 4.06 & 661.48 & 21.30 & 5.94 & 34.6 & 386 \\
\hline bentifer & mediun & 1.00 & 1.000 & 6.080 & bel type & ubstrate & 100 & 1.00 & 1.00 & 1.00 & 100 & 00 & 1.0 \\
\hline
\end{tabular}

Table 6. Calculation of respiratory and glycolytic acidification. Columns headed in yellow indicate values to be entered from calculation (e.g., BP, max $\mathrm{H}^{+} / \mathrm{O}_{2}$ ), or from data collection (e.g., ECAR tot, OCR). Please click here to view a larger version of this table. | Please click here to download this table as an Excel spreadsheet.

\section{Contributions of glycolysis and respiration to PPR after correction}

Figure 3 shows the graphical output of data calculated as in Table 6 for native rates of glycolytic and respiratory acidification, rates following oligomycin addition (Port A), and rates following FCCP addition (Port B). These data clearly demonstrate how the proportions of respiratory and glycolytic acidification change with choice of substrate (glucose vs. control (ctl) with none added) and with mitochondrial status (native function vs. pharmacologically altered function).

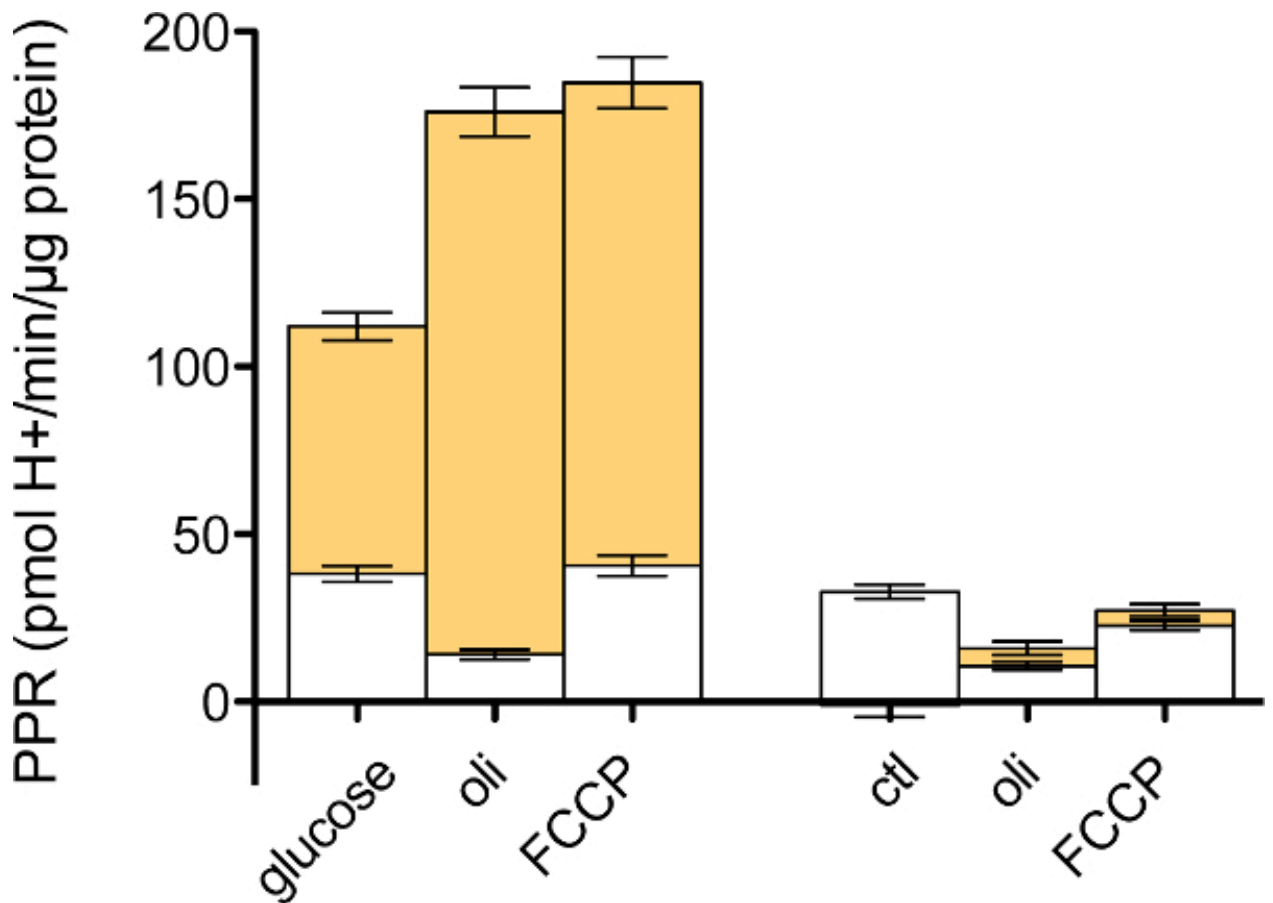

Figure 3. Proton production rate (PPR) from glycolytic and respiratory sources. PPR from respiration (open portions) and glycolysis (filled portions) of $\mathrm{C} 2 \mathrm{C} 12$ cells calculated using Equation 5 with added glucose (three left bars) or without added glucose (three right bars). Data from ${ }^{6}$. All data represent mean \pm SEM of $n=8$ biological replicates.

\section{Discussion}

Extracellular acidification is an easily measured indication of cellular metabolic rate. To properly determine the rate of cellular glycolysis (as defined by lactate production) it is critical to know the buffering power of the assay medium, and to convert the extracellular flux measurements of oxygen consumption and acidification to proton production rates. By performing this calculation, the acidification resulting from $\mathrm{CO}_{2}$ released in the citric acid cycle can be subtracted, leaving the acidification that results from lactate production.

The multiple different ways given here to measure buffering power for this correction carry different advantages and disadvantages. External measurement using a $\mathrm{pH}$ probe is highly accurate and reproducible, but may not reflect small differences in pH detection introduced by the 
fluorophores contained within the assay plate, the addition of compounds during the assay, or the presence of the cells themselves. The in-plate $\mathrm{pH}$ measurements address these issues, but also introduce varying degrees of experimental noise.

The $\mathrm{CO}_{2}$ correction to ECAR allows for the first time the unambiguous and quantitative calculation of glycolytic rate, and reveals variation in respiratory and glycolytic contribution to total ECAR during the course of an experiment. Using Equation 5 and the measurements of OCR, ECAR, and buffering power, glycolytic rate can be calculated using the simple spreadsheet provided (Table 6). This rate can be verified by posthoc lactate measurement if desired ${ }^{6}$. In cells where the pentose phosphate pathway is highly active, the use of pathway inhibitors such as 6 aminonicotinamide may be useful to isolate glycolytic rate. Calculation of the contributions of both $\mathrm{CO}_{2}^{-}$and lactate-derived $\mathrm{H}^{+}$from the total measured Extra Cellular Acidification Rate and Oxygen Consumption Rate is an invaluable tool for using extracellular flux data to make powerful and quantitative statements about metabolic activity.

Using the procedures described here, including various modifications for measuring buffering power, and optimizing the extracellular flux experiment for the cells under investigation and data desired, the rate of glycolysis in intact cells can be quantified under a wide range of experimental conditions. This method is limited to cells that can grow in adherent culture on (or cells or organelles that can be adhered to) a polystyrene surface. It is most reliable when cultured cells are homogenous and confluent, though useful data may still be obtained over a range of these conditions. The calculations require some knowledge of the metabolism of the cells, as max $\mathrm{H}^{+} / \mathrm{O}_{2}$ ranges from 0.65 to 1.0 for full oxidation of different substrates and more for partial oxidation ${ }^{6}$, however, if the cells are known to oxidize glucose, a value of 1.0 can be assumed.

Though relevant to all metabolic characterization, this method may be particularly helpful when used in systems in which a shift between respiratory and glycolytic metabolism to maintain cellular ATP supply is a critical phenotype, including the characterization of stem cells and tumor-derived cancer cells. Understanding metabolic control alterations in these and other contexts will allow a greater degree of sophistication and accuracy in the experimental design and analysis of these cell types.

\section{Disclosures}

Dr. Shona Mookerjee declares that she has no competing financial interests. Dr. Martin Brand has consulted for Seahorse Biosciences, which produces instruments and reagents used in this Article.

\section{Acknowledgements}

We thank David A. Ferrick and David G. Nicholls for contributing to project conception and presentation, Renata L.S. Goncalves and Akos A. Gerencser for data not shown here and for helpful discussions, Barbara Liepe for XF24 consumables, and Andy Neilson for input in developing Eq. (5).

\section{References}

1. Brand, M.D., \& Nicholls, D.G. Assessing mitochondrial dysfunction in cells. Biochem. J. 435 (2), 297-312 (2011).

2. Gerencser, A.A., et al. Quantitative microplate-based respirometry with correction for oxygen diffusion. Anal. Chem. 81 (16), 6868-6878 (2009).

3. Divakaruni, A.S., Paradyse, A., Ferrick, D.A., Murphy, A.N., \& Jastroch, M. Analysis and interpretation of microplate-based oxygen consumption and pH data. Meth. Enzymol. 547, 309-54 (2014).

4. Renner, K., Jansen-Dürr, P., \& Gnaiger, E. Biphasic oxygen kinetics of cellular respiration and linear oxygen dependence of antimycin A inhibited oxygen consumption. Mol. Biol. Rep. 29 (1-2), 83-87 (2002).

5. Helmlinger, G., Sckell, A., Dellian, M., Forbes, N.S., \& Jain, R.K. Acid production in glycolysis-impaired tumors provides new insights into tumor metabolism. Clin. Cancer Res. 8 (4), 1284-91, (2002).

6. Mookerjee, S.A., Goncalves, R.L.S., Gerencser, A.G., Nicholls, D.G., \& Brand, M.D. The contributions of respiration and glycolysis to extracellular acid production. Biochim. Biophys. Acta. 1847, 171-81 (2015).

7. Wu, M., et al. Multiparameter metabolic analysis reveals a close link between attenuated mitochondrial bioenergetic function and enhanced glycolysis dependency in human tumor cells. Am. J. Physiol. 292 (1), C125-C36 (2006).

8. Nadanaciva, S., et al. Assessment of drug-induced mitochondrial dysfunction via altered cellular respiration and acidification measured in a 96-well platform. J. Bioenerg. Biomembr. 44 (4), 421-437 (2012).

9. Pelletier, M., Billingham, L.K., Ramaswamy, M., \& Siegel, R.M. Extracellular flux analysis to monitor glycolytic rates and mitochondrial oxygen consumption. Meth. Enzymol. 542 125-149 (2014).

10. Nicholls, D.G., Darley-Usmar, V.M., Wu, M., Jensen, P.B., Rogers, G.W., \& Ferrick, D.A. Bioenergetic profile experiment using C2C12 myoblast cells. J. Vis. Exp. 46 (46), 2511 (2010).

11. Rogers, G.W., et al. High throughput microplate respiratory measurements using minimal quantities of isolated mitochondria. PLoS ONE. 6 (7), e21746 (2011).

12. Seahorse Biosciences. F24 Extracellular Flux Analyzer and Prep Station Installation and Operation Manual., Version 1.7, (2010).

13. Blau, H., Chiu, C., \& Webster, C. Cytoplasmic activation of human nuclear genes in human heterocaryons. Cell. 32, 1171-1180 (1983). 